\title{
Chapter 5 \\ Rites, Rights, and Water Justice \\ in Karen State: A Case Study \\ of Community-Based Water \\ Governance and the Hatgyi Dam
}

\author{
Saw John Bright
}

\subsection{Introduction}

The issue of justice lies at the heart of debates over water governance in Myanmar. Nowhere is this more apparent than the contested plans for five large hydropower dams in politically contested areas on the Salween River's mainstream, including the Hatgyi Dam in Hpa An District, Karen State (Salween Watch 2016). Initial preparations for the Hatgyi Dam have already been linked to violent armed conflicts and human rights violations, and further harm to livelihoods and cultural values of communities could ensue if construction proceeds (Magee/Kelley 2009; KRW 2016; Middleton et al., Chap. 3, this volume). The dam site is located in an area of "mixed administration" where the Union Government, the Karen State Government, the Karen National Union (KNU), and the Democratic Karen Benevolent Army (DKBA; before 2010 known as the Democratic Karen Buddhist Army) compete for political authority, legitimacy, and territorial control (South 2018). For over 60 years, the Karen National Liberation Army (KNLA) and its political wing the KNU have been in conflict with Myanmar's Union Government and the Myanmar armed forces (the Tatmadaw) demanding for the right to self-determination and to govern its own natural resources (Jolliffe 2016). The dam site itself is partly control by the DKBA, which is an ethnic armed organization (EAO) that splintered from the KNLA in 1994 and that was first allied with the Tatmadaw, but following the 2010 elections became independent from them.

Eighty kilometers downstream from the Hatgyi Dam site on the Salween River is Kaw Ku Island and the nearby Daw Lar Lake that connects to the Salween River mainstream (KESAN 2018). Five villages are located around Daw Lar Lake with a combined population of more than 8,000 people. In this area, the State-level Karen State Government has a stronger presence compared to the Hatgyi Dam site

Saw John Bright, Water Governance Program Coordinator, Karen Environmental and Social Action Network (KESAN); Email: hserdohtoo@gmail.com.

(C) The Author(s) 2019

C. Middleton and V. Lamb (eds.), Knowing the Salween River: Resource Politics

of a Contested Transboundary River, The Anthropocene: Politik-Economics-

Society-Science 27, https://doi.org/10.1007/978-3-319-77440-4_5 
upstream, and claim formal authority over resource management. At the same time, the government's authority is a relatively weak presence in the area on a day-to-day basis, and the five villages have governed the Daw Lar Lake and seasonally-flooded Kaw $\mathrm{Ku}$ Island through evolving local customary arrangements as a form of local authority over water resources. More recently, with support from the NGO Karen Environment and Social Action Network (KESAN), a project has sought to consolidate Community-Based Water Governance (CBWG) in a quest to gain recognition from the Karen State Government on the right to govern these resources principally through a local committee formed of the community themselves (see also, Götz, Chap. 6, this volume).

Researchers of water issues in Southeast Asia have begun to address the concept of justice in water governance, arguing that there is a need to identify the winners and losers in decision-making towards water (Lazarus et al. 2011; Middleton/ Pritchard 2016). The purpose of this chapter is to examine the competing claims for justice in water governance on Kaw Ku Island and around Daw Lar Lake and work undertaken to establish CBWG, in the context of plans for the Hatgyi Dam located upstream. Conceptually, I draw on the work of Badenoch/Leepreecha (2011) who studied watershed governance in Northern Thailand through the lens of 'Rights' and 'Rites' to analyze claims to legitimacy and the power relations. Rites-based approaches are understood as locally-defined natural resource management arrangements that center upon cultural norms and local knowledge. Meanwhile, Rights-based approaches are formalized and legalistic approaches to resource governance that are normally recognized by the state and codified in laws and policies (see also Dore 2014). There is a complex relationship between the central government and other actors in the Hatgyi Dam area and downstream at Kaw Ku Island and the Daw Lar Lake. The concepts of Rights and Rites enables me to explore the formal and informal means by which a range of actors (central-level and state-level government; KNU, DKBA, and communities) interact around the issue of water governance, the relative influence of each actor and power relations between them, and ultimately the issue of justice in water governance.

The interviews for this research were principally undertaken between November 2015 and July 2016. I conducted in-depth interviews, informal dialogues and participant observation at various types of meetings (policy dialogues; conferences; workshops, etc) at the national level, state level; and at the village/community level. My interviews with those who are working on water governance issues in Myanmar included representatives of State Government $(n=2)$, the National Water Resource Committee $(n=1)$, and research institutes $(n=2)$. I held three focus group discussions in Mikiyan Village with representatives from all five villages around Daw La Lake, and five in depth interviews with community leaders. Many of the meetings and dialogues that I have joined both during the interview period and more recently related to my work at the time with KESAN as Water Governance Program Lead.

In this chapter, I explore how 'Rights' and 'Rites' have long shaped the interaction between state and community in resource governance in Karen State. I argue that to ensure inclusive decision-making processes and therefore social justice in water governance in Myanmar, formal policy and institutional arrangements must 
reflect Rights but also accommodate Rites. The chapter is structured as follows. In the next section, I analyze CBWG at Daw La Lake and Kaw Ku Island through a Rites and Rights lens. I then discuss the decision-making process to date for the Haygyi Dam and the role of the civil society movement challenging the project. In the subsequent discussion, I synthesize these two aspects of water governance on the Salween River in Karen State to discuss water justice from the perspective of Rights and Rites.

\subsection{Community-Based Water Governance Arrangements in Karen State}

To better manage local resources, and in response to large-scale development projects such as the proposed Hatgyi Dam upstream, the Karen local community living along the Salween River near Daw La Lake and Kaw $\mathrm{Ku}$ Island have undertaken a local initiative known as CBWG. CBWG is intended to build community members' capacity to lead and implement their own vision of governance and management of natural resources. Within the CBWG process and collaborating with the NGO KESAN, community members are center to decision-making. Throughout the learning process, traditional resource use practices are explored as a basis to develop a community resource management plan. The intention is that the process of CBWG will ensure recognition and support from the Karen State Government for the community's approach. Both Rights and Rites are reflected in the CBWG model and are the basis of the community claiming legitimacy for local authority over the Salween River's governance in their area.

In the next section, I detail the existing local knowledge and practices towards managing water resources in Daw La Lake and on the Kaw Ku Island. I then show how the CBWG arrangements have been undertaken through a community learning process, leading to the establishment of a local governance institution.

\subsubsection{Community's Rites at Daw La Lake and Kaw Ku Island}

The ecosystems of the Salween River, Daw Lar Lake and Kaw Ku Island are intimately connected (KESAN 2018). Daw La Lake is approximately 26 square kilometers when fully flooded and is located on the western bank of the Salween River, $12 \mathrm{~km}$ upstream from Hpa An town. It is connected to the Salween River via a large natural stream. Kaw $\mathrm{Ku}$ Island is approximately $1.2 \mathrm{~km}^{2}$ when fully exposed, and is located within the Salween River's mainstream, nearby to the lake. The seasonal fluctuations of the Salween River, to which people have long adapted, shape the ecosystems and livelihoods around Daw Lar Lake and on Kaw Ku Island. 
When the river rises and floods in the rainy season (July-September), Daw Lar Lake expands, while Kaw Ku Island is submerged beneath the water. This period is good for fishing. As the Salween River drops and the flood water recedes in the summer (October-December), Daw Lar Lake diminishes in size and Kaw Ku Island appears again. During this period, cash crops such as mung bean and peanuts, are planted on Kaw Ku Island (Ko Thout Kyar Interview, 11 November 2015) (Table 5.1: Seasonal farming calendar for Kaw Ku Island and Daw La Lake). With the complex land/waterscape that annually transitions between being flooded and dry, the villages in this area have locally created systems (i.e. non-written rules) for governing and using the productive, seasonally-changing natural resource base.

The seasonally-flooded Kaw $\mathrm{Ku}$ Island is shared by three villages located on both banks of the Salween River, namely: Mizan Village, Motekadi Village and Kaw Ku Village. When the Salween River's floodwaters recede at the beginning of October highly fertile soil becomes exposed that is well-suited to seasonal plantings. During this time, between 70 and 80 families farm on the island, and each family earns approximately US $\$ 3,000$ per season (U Myint Sein Interview, 25 January 2016). This income is generated over three to four months when the island is used for growing seasonal crops. As a seasonally flooded island, from the perspective of formal law its land ownership is ambiguous. Some parcels of land on the island have a land registration certificate issued by the Land Department of the General Administration Department (GAD) under the Ministry of Interior. However, the majority of land use on the island is managed through informal means. The heads of the villages usually lead management for sharing the use of the island including dispute resolution, although they also have to consult with the monks, village elders, and informal community leaders including women representatives to facilitate decision-making (Ko Nyan Win Interview, 12 November 2015). However, as the farmers here are not sure whether the government land use policy on the island will change, they are working with the CBWG project towards defining more clearly the village-led management for the island to reduce the perceived risk of this external threat.

Regarding Daw La Lake, there are five villages located around it, namely: Mikayin Village, Motekadi Village, Kangyi Village, Kankalay Village, and Kedauk Village. During the rainy season, when the Salween River level rises, Daw La Lake floods and fish migrate from the river to breed and grow in the lake (Ko Kyaw Hla Interview, 12 November 2015). At this time, the main occupation of the community members is fishing. However, fishing is conducted all year round and the largest fish are actually caught when the water becomes low in the lake during March and April. The flood also nourishes the soil, which is important for farming once the water recedes (Daw Mya Nyut Interview, 4 February 2016). When the water recedes, the exposed land is used for seasonal crops and vegetables. The farmers main cash crop in these villages is rice. The farmers also plant vegetables together with beans. After harvesting the agricultural crops, the land is used for grazing buffalos and cows (Elders Group Interview, 26 February 2016).

Around Daw La Lake, the community members have created informal rules for lake and land use. Rather than use official maps to define resource use boundaries, 
Table 5.1 Seasonal farming calendar for Kaw Ku Island and Daw La Lake

\begin{tabular}{|c|c|c|c|c|}
\hline \multirow{2}{*}{$\begin{array}{l}\text { Month (Burmese } \\
\text { and Karen names in } \\
\text { brackets) }\end{array}$} & \multicolumn{4}{|l|}{ Farming practice } \\
\hline & $\begin{array}{l}\text { "Muyin Rice" (mixed land } \\
\text { and water) grown both } \\
\text { around Daw La Lake and } \\
\text { on Kaw Ku Island }\end{array}$ & $\begin{array}{l}\text { "Farm Rice" } \\
\text { (on land) } \\
\text { grown } \\
\text { around Daw } \\
\text { La Lake }\end{array}$ & $\begin{array}{l}\text { "Patat Rice" } \\
\text { (in water) } \\
\text { grown } \\
\text { around Daw } \\
\text { La Lake }\end{array}$ & $\begin{array}{l}\text { Beans and other } \\
\text { vegetables } \\
\text { grown mostly } \\
\text { on Kaw Ku } \\
\text { Island }\end{array}$ \\
\hline $\begin{array}{l}\text { January (Burmese: } \\
\text { Pyatho, Karen: Lar } \\
\text { Plu) }\end{array}$ & Prepared and planted & & & \\
\hline $\begin{array}{l}\text { February } \\
\text { (Burmese: } \\
\text { Taboetwal, Karen: } \\
\text { Tha Lae) }\end{array}$ & & & & \\
\hline $\begin{array}{l}\text { March (Burmese: } \\
\text { Tabaung, Karen: } \\
\text { Htay Ku) }\end{array}$ & & & & Harvested \\
\hline $\begin{array}{l}\text { April (Burmese: } \\
\text { Tagu, Karen: } \\
\text { Thway Kaw) }\end{array}$ & Harvested & & & \\
\hline $\begin{array}{l}\text { May (Burmese: } \\
\text { Kason, Karen: Day } \\
\text { Nyar) }\end{array}$ & & & & \\
\hline $\begin{array}{l}\text { June (Burmese: } \\
\text { Nayon, Karen: Lar } \\
\mathrm{Ku} \text { ) }\end{array}$ & & $\begin{array}{l}\text { Prepared and } \\
\text { planted }\end{array}$ & & \\
\hline $\begin{array}{l}\text { July (Burmese: } \\
\text { Waso, Karen: } \\
\text { Lar Nwei) }\end{array}$ & & & & \\
\hline $\begin{array}{l}\text { August (Burmese: } \\
\text { Wakhaung, Karen: } \\
\text { Lar Khoe) }\end{array}$ & & & & \\
\hline $\begin{array}{l}\text { September } \\
\text { (Burmese: } \\
\text { Tawthalin, Karen: } \\
\text { Lar Khut) }\end{array}$ & & & $\begin{array}{l}\text { Prepared and } \\
\text { planted }\end{array}$ & \\
\hline $\begin{array}{l}\text { October (Burmese: } \\
\text { Thadingyut, Karen: } \\
\text { Sie Mu) }\end{array}$ & & Harvested & & $\begin{array}{l}\text { Prepared and } \\
\text { planted }\end{array}$ \\
\hline $\begin{array}{l}\text { November } \\
\text { (Burmese: } \\
\text { Tazaungmone, } \\
\text { Karen; Lar Nor) }\end{array}$ & & & Harvested & \\
\hline $\begin{array}{l}\text { December } \\
\text { (Burmese: Nadaw, } \\
\text { Karen: Lar Plue) }\end{array}$ & & & & \\
\hline
\end{tabular}

Source Interviews and fieldwork conducted by the author

Note Burmese/Karen calendar months should be referred to as the primary timing for this seasonal calendar, as the Burmese/Karen calendar months do not always correspondent precisely with the days of the months in the Roman Calendar 
Table 5.2 Community learning process towards CBWG

\begin{tabular}{l|l|l}
\hline & Step & Activities \\
\hline 1 & Laying the ground work & $\begin{array}{l}\text { Mobilize community members and build up } \\
\text { capacity to facilitate the CBWG process. Form } \\
\text { an interim committee to assist the learning } \\
\text { process until the management plan is established }\end{array}$ \\
\hline 2 & Documentation of natural resources & $\begin{array}{l}\text { Map out resource use, seasonal calendar and } \\
\text { livelihood cycle. Investigate resource boundaries } \\
\text { and facilitate a negotiation process between } \\
\text { various users of resources }\end{array}$ \\
\hline 3 & $\begin{array}{l}\text { Strengthening community } \\
\text { governance for natural resource } \\
\text { management }\end{array}$ & $\begin{array}{l}\text { Develop a management plan with community } \\
\text { regulations and institutions to enforce it }\end{array}$ \\
\hline 4 & $\begin{array}{l}\text { Preparing community action plan for } \\
\text { livelihood support }\end{array}$ & $\begin{array}{l}\text { Integrate livelihood support into management } \\
\text { plan and ensure equitable regulations }\end{array}$ \\
\hline 5 & Monitoring and evaluation & $\begin{array}{l}\text { Create community platform for resource } \\
\text { management and advocacy, and a permanent } \\
\text { village committee. Ensure the sustainability of } \\
\text { resource management plan }\end{array}$ \\
\hline
\end{tabular}

Source Interviews and fieldwork conducted by the author

informally agreed boundaries have been agreed between the villages using landmarks such as big trees, mountains and small streams, and there are no territorial disputes between the five villages (Ko Nyan Win Interview, 12 November 2015). Regarding disputes over fishing practices, informal dispute handling mechanisms between the five villages exist that have been further developed in the CBWG process (see next section and Table 5.2: Community learning process towards CBWG). This has led to practices and rules to avoid overfishing and threats to fish species, including restrictions on the types of equipment used for fishing. Small-mesh fishing nets and electric shock devices, for example, are not permitted. If someone is found using them, the first time they are given a warning, and if there is repeated use, the equipment is confiscated (but only if the equipment has a low monetary value) (Youth Groups Interview, 26 February 2016). It is also not permitted to catch fish during the hatching period because it can harm the breeding of the fish species; for example, in Mikayin Village traditionally fishing is not permitted during the flooded period from Waso (July) to Tawthalin (September). Meanwhile, the month of Nadaw (December) is a religious period. At this time, there are meditation retreats and no one can go fishing as it is not permitted to kill during this period according to Buddhist teaching (Elders Group Interview, 26 February 2016).

Until now, similar to land management at Kaw Ku Island, representatives of the five villages meet together to make decisions on setting rules and regulations and disseminating them based on a general consensus. However, as there is at present no government recognized legal protection to acknowledge their traditional ownership and management of these natural resources, they are concerned about their long-term entitlement to access the lake. 


\subsubsection{A Rights Approach to the Daw La Lake}

Daw La Lake is crucial to the food and water security of villagers living around it. Yet, according to community leaders interviewed, the Karen State Government does not act in a way that acknowledges and respects this. In 2013, for example, during the Union Solidarity and Development Party (USDP) government period (2011-2016), the Karen State Government Fisheries Department sought to grant Daw Lar Lake as a concession to a private company for commercial fishing (KESAN 2018). The communities surrounding the lake were not consulted on this decision, and once they learned of the plan they resisted the plan. They organized a public signature campaign and submitted a letter to the Karen State Chief Minister claiming that the lake had been owned by their communities since their ancestors and is a key source of livelihood for fishing and farming.

Realizing the potential threat from such initiatives of the Karen State Government, community leaders and members settled on a plan to establishment a CBWG model in Daw Lar Lake that would enable them to advocate for legal recognition of the village's claim to manage the lake and thus reduce the likelihood that the Lake would be sold as a concession to private companies. Table 5.2: Community learning process towards CBWG details the five main steps in the community learning process for the CBWG model. Through this process, local institutional arrangements have emerged that reflect the traditional practices of resource governance and are a claim to the community's authority over the management and ownership of Daw Lar Lake.

The local histories in these Karen areas are complex and have been in one way or another impacted by armed conflict for over half a century (South 2018). In laying the groundwork for CBWG, confidence and trust had to be carefully built between the communities and the NGO KESAN that partnered with the communities to guide the CBWG process. A series of events towards a cement factory that was proposed nearby to Mikayin Village in 2013 coincidently led to deepened understanding and trust between the community and KESAN. The cement factory would have had a significant negative impact on Mikayin Village's culture and livelihood. Community members from the village networked with other villages nearby and cooperated with KESAN to stop the cement factory's construction. This was an experience that led to the realization amongst the community members that they could influence policy if they mobilized themselves together. Following this, community members from Mikayin Village proposed to work with KESAN to develop a conservation plan for Daw La Lake with the ambition to gain legal recognition from the Karen State Government.

Subsequently, staff from KESAN worked with local community leaders to facilitate discussions and meetings in the five villages around the lake to establish village committees in late 2015. However, it was not an easy task as these communities have long been living under the threat of conflict and an authoritarian regime that had influenced their confidence to establish community-led committees. Various community members were concerned that they would be perceived by the 
government as breaking the law if they participated in the created village committee, as it is not a registered organization. However, a core group of community leaders were confident in their knowledge of how to utilize political space and seek legal opportunities in the context of the new semi-civilian government. They therefore established an interim committee formed of members from the five villages in early 2016.

The purpose of this interim committee is to facilitate the CBWG process that is working towards the creation of a lake conservation and management plan (KESAN 2018). In the longer term, a permanent management committee will be established. Members of the interim committee were selected democratically by representatives of the existing village committees, which themselves are democratically elected by the community members. Gender equality was also carefully accounted for. The interim committee facilitates dialogue between the different users of the lake that include both fishers and farmers across the five villages. Their role includes to help resolve disputes related to resource management; for example, in some areas of the lake, fishers want to retain flood water for fishing, while farmers want the water to rapidly recede to grow rice and other crops.

Traditionally, in Karen communities, men and women share responsibilities for livelihood activities such as fishing and farming. For example, in some families women go fishing, while in other families women make fishing nets and baskets while men fish. However, overall men have a greater say in resource management decisions in the community. Women are keen to - and do - take part in some village meetings, but do not normally hold administrative duties in the village. There are exceptions, however. For example, in Mikayin Village there are four women "ten-household" leaders who take responsibility for keeping minutes of village meetings related to the management of the lake. Thus, despite strong prevailing cultural norms, there is some flexibility for women to take leadership roles (Women's Group Interview, 26 February 2016).

The CBWG initiative around Daw La Lake is a work in progress. With the interim committee now established, community members and KESAN are engaged in activities to document natural and man-made resources and their use around the Daw Lar Lake, and to agree upon boundaries and associated resource uses within them. To this end, the interim committee selected community learning facilitators (CLFs) from the five villages to assist them. Most are youths aged between 25 and 35 , who were selected with the intention to encourage the younger generation to actively engage in decision-making processes around the management and governance of natural resources and environmental conservation in their community. The CLFs have worked closely with KESAN to document activities on the use of natural resources and facilitate the preparation of a resource management plan with livelihood support. They also conduct village meetings and an annual forum, facilitate monitoring and evaluation activities, and mobilize and encourage the community members.

While the CBWG initiative has made important progress towards rendering visible the communities' claims to govern local natural resources in support of their livelihoods, there are a number of threats. They range from the proposal of the 
Karen State Government mentioned above to auction the Daw Lar Lake as a private fishing concession, to other threats such as plans for rock quarries and expanding rubber plantations, as well as the proposed Hatgyi Dam upstream that I discuss in more detail in the next section. These threats reveal the centralized nature of decision-making that exclude communities' Rites - and often Rights - in the process, and that have motivated the community to seek legal recognition of their local CBWG institution and livelihood systems.

\subsection{Hatgyi Dam: Centralization of Decision-Making and Civil Society Response}

Plans for large dams on the Salween River first emerged in 1979 when the Electricity Generating Authority of Thailand (EGAT) initiated a series of feasibility studies for water diversions and later hydropower dams on tributaries and the mainstream (see also, Middleton et al., Chap. 3, this volume). Initial studies gained political momentum when a Memorandum of Understanding was signed between the Thailand and Myanmar (military junta) governments in July 1996 for Thailand to purchase 1,500 MW of hydroelectricity from Myanmar by 2010 (TERRA 2006). The initial design of the Hatgyi Dam, prepared in 1999, proposed a 300 MW "run-of-river" dam. However, a subsequent study published in November 2005 redesigned and significantly enlarged the project to 1,200 $\mathrm{MW}$ with a 33-m-high dam. In December 2005, EGAT signed a Memorandum of Agreement with the Myanmar military junta government's Department of Hydroelectric Power to proceed with the Hatgyi Dam (TERRA 2006). The entire process was shrouded in secrecy (Magee/Kelley 2009), with no consideration of local communities concerns in Myanmar neither from a Rights nor Rites perspective.

Military activities have occurred around the Hatgyi dam site creating fear and insecurity for communities living in the area (see also TERRA 2006, 2014; Magee/ Kelley 2009). In June 2009, for example, a major military attack by the Tatmadaw and the at-the-time allied DKBA occurred on the KNU, in an area only $17 \mathrm{~km}$ away from the proposed Hatgyi Dam site. The intention of the attack was to secure the wider area around the dam site, which the KNU controlled. As a result, 3,500 villagers were forced to flee across the Thai border (KHRG 2009). Three years later, on 13 January 2012, the KNU and the Tatmadaw signed an initial ceasefire agreement that opened the door to political dialogues on peace and a federal settlement between the Myanmar Union Government and the KNU. However, even despite this agreement, contradictory activities occurred on-the-ground, as the number of Myanmar military troops deployed into Karen areas increased (Wade 2012) and military attacks have continued until present with major incidents in 2014, 2015 and 2016 (KRW 2014; KHRG/KRW 2018). 
Hence, during the period of conflict, and during the ceasefire, the Myanmar Union Government has tried to advance plans for dams on the Salween River (Salween Watch 2016). Civil society groups, in response, have sought to challenge these plans, raising a range of concerns related to the projects' environmental and social impacts, human rights violations, and that the projects are being pushed forward even as conflict in the areas continue and obstruct the peace negotiations (KPSN 2015). For example, in 2014, 80,000 local people from Shan, Karenni, Karen and Mon States and more than 130 civil society organizations and political parties in Myanmar signed a petition urging an immediate halt to the six dams planned by the Union Government on the Salween River. Furthermore, a network of community leaders and community-based organizations have organized under the name "Save the Salween Network" who have regularly issued statements stating that the Salween River is the lifeblood of local people, providing livelihood opportunities and links with cultural identity (e.g. SSN 2016).

Eighty kilometers downstream of the dam site, in the villages at Daw La Lake and Kaw Ku Island, community leaders have expressed their serious concern about the government's plans to build the Hatgyi Dam. One community leader from Kaw $\mathrm{Ku}$ Village said:

If the dam is built, the natural balance will be completely destroyed. The river's flows will be blocked by the dam, and there will be no seasonal lake or island, and no chance for fishing and farming. (Ko Thout Kyar Interview, 11 November 2015)

These communities have received no official information from the government, but just hear about the project from the media and information received from civil society organizations, including KESAN, Karen Rivers Watch, Save the Salween Network and Burma Rivers Network. These organizations have conducted research and undertake advocacy. Community members receive information both directly or indirectly from CSOs publications and media coverage talking about Salween dams. Some also participate in public events and meetings organized by CSOs to mark the international day of action for rivers on March 14 annually. They are concerned who will take the responsibility for their lives if the dam is built.

The Myanmar Union Government does not have clear policies or legal mechanisms to address conflict-sensitive water disputes such as on the Salween River neither domestically nor at the transboundary-level. The Union-level National Water Resources Committee (NWRC), created in 2013, is chaired by the Second Vice President, and co-chaired by the Union Minister of the Ministry of Transport, with representatives from different government ministries. Reflecting the political character of the committee, the NWRC as formed under the USDP of President U Thein Sein was reformed in June 2016 under the subsequent National League for Democracy (NLD) government with a revised membership (Phyu 2016). The NWRC is seeking to define a central role for itself in policies related to the water sector in Myanmar. To date, the committee has developed a National Water Policy, published in March 2014, and at the time of writing is working on a Water Law. However, the details of the process to develop the Water Law are not publicly available (U Cho Cho Interview, 25 July 2016). 
Despite the absence of a comprehensive Water Law, there have been many investments related to water resources in Myanmar, including in hydropower projects. The most relevant water-related legislation at present is the Conservation of Water Resources and Rivers Law (2006), which addresses three main themes: navigation on rivers; water infrastructure, in particular ports and constructions alongside rivers; and water pollution. The scope of this law, which excludes hydropower and irrigation infrastructure, mandates the Ministry of Transportation and Communications, which also explains the scope of the law. Another related legislation regards Environmental Impact Assessment (EIA). The EIA Procedure approved by the cabinet in November 2015 - was drafted with support from the Asian Development Bank, and although it was said to be based on guidelines from the International Finance Corporation it fails to cover complaint mechanisms and only poorly recognizes community rights as it does not, for instance, mention "Free, Prior and Inform Consent," both of which are important community rights for ethnic nationalities.

Which government department leads the decision-making over the Salween dam projects is also ill-defined. During the USDP administration (2010-2015), the Ministry of National Planning and Economic Development and the Ministry of Electric Power were the key ministries responsible for hydropower construction in Myanmar (Doran et al. 2014). Subsequently, under the NLD government (2016-present), following a consolidation of various ministries, the new Ministry of Electric Power and Energy takes a key role in hydropower policymaking (Parliamentarian Interview, 29 July 2016). The Ministry of Natural Resources and Environmental Conservation (MONREC), formed in March 2016, also takes a role in decision-making to enforce environmental regulations. However, there remains ambiguity on the precise role of each, together with that of other relevant ministries. Until now, decisions that have sought to push forward the Hatgyi Dam have been taken at the Union-level, with little role for the State-level Government.

Civil society groups concerned about plans for hydropower on the Salween River had hoped that the new NLD government would revise the government's position on the dams, as its 2015 Election Manifesto states:

\footnotetext{
The construction of the large dams required for the production of hydropower causes major environmental harm. For this reason, we will generate electricity from existing hydropower projects, and repair and maintain the existing dams to enable greater efficiency.
}

However, in practice, since coming to power, the NLD government has not clearly removed the Salween Dams from the electricity-sector agenda. According to Myanmar's 2008 Constitution Article 445, it is stated that any new government will have to implement the projects agreed by the previous government. Therefore, the NLD government has had to navigate various legal issues in decision-making over the Salween River dams, even though the agreements of the previous governments were made without information disclosure or consultation with the public. 


\subsection{Federalism, the Peace Negotiation Process and the Hatgyi Dam}

Underlying the issue of large dam decision-making in the Salween River basin are the issues of decentralization, federalism and the peace negotiation process, in particular with regard to resource governance and revenue sharing (see also Middleton et al., Chap. 3, this volume). The Karen State Chief Minister, in an interview stated that:

We are aware of the negative impacts of the Hatgyi Dam on the environment and people, but we are not sure exactly how to deal with the Hatgyi Dam as the decision was made by the Union Government of the previous Government. (Daw Nan Khin Htway Myint Interview, 19 June 2016)

A Member of Parliament from the NLD at the Union-level, elected to the Lower House and who is Chairperson of the Lower House Committee for Natural Resources Affairs, also stated that State Governments should have decision-making powers for development projects in their areas (U Soe Thura Htun Interview, 29 July 2016). Reflecting this perspective, the Myanmar Times newspaper reported that the Shan State government also asserted that it planned to stop all hydropower projects in Shan State (Htwe 2016). However, the controversial 2008 constitution states under Schedule Two on the authority delegated to the State-level government that:

4. (a) Medium and small scale electric power production and distribution that have the right to be managed by the Region or State not having any link with national power grid, except large scale electric power production and distribution having the right to be managed by the Union.

Yet, given the complexity and implications of large dams, the actual role in decision-making of the State-level Government still requires further clarification. Beyond this, the legal entitlements of communities who would be affected by such projects if they proceed are even more ambiguous.

The rush towards foreign investment and development projects in conflictaffected areas are resulting in human rights abuses in ethnic areas in Myanmar. This is leading to distrust and questions by some ethnic leaders and the wider ethnic people's community towards the political process, including on its inclusiveness and commitment to decentralizing decision-making powers under a federal system versus affirming the authority of the Central Government over ethnic areas (KPSN 2018). In response, ethnic civil society groups and political parties at the local, state and national-levels have been demanding customary rights in national laws and policies, including in the Water Law now reportedly under preparation but not yet made publicly available (BRN 2017). Many have also called for a moratorium on mega-development projects, such as the Hatgyi Dam, until the peace negotiations are fully concluded, which would establish Myanmar's new federal political structure and accordingly a new Constitution with new rules on decentralized resource governance (BEWG 2017). For example, the KNU Vice Chairperson, Padoh 
Naw Seporah Sein, stated in a documentary interview in 2016 that the KNU has a clearly stated policy that:

... a moratorium for the Hatgyi Dam project and other Salween dams should be made and no discussion on this before peace has settled down in the ethnic areas and resource governance and federal issues are sorted out. (Fawthrop 2016)

Meanwhile, communities living alongside the Salween River near the Hatgyi Dam have been almost entirely excluded from the decision-making process to date. Only once the political negotiations are complete for peace, and it is detailed within a new Federal Constitution, can the conditions really be in place for meaningful participation and deliberation amongst river-side ethnic communities.

\subsection{Towards a Rites and Rights Approach for Justice in Water Governance}

In the recent literature on environmental justice, attention is paid to distributional justice, procedural justice, and recognitional justice (Walker 2012). Distributive aspects of justice refer to the fair distribution of environmental harms, risks and benefits. Procedural justice considers the ways in which decisions are made, who is involved, and who has influence. Justice as recognition addresses who is and is not valued, and incorporates social and cultural (lack of) recognition. Furthermore, there are various formal and informal arenas across multiple scales within which decision-making processes and access to justice take place (Middleton/Pritchard 2016). In this concluding section, I link these notions of justice to the situation faced by the river-side communities seeking to defend their claims for their Rights and Rites in relation to access, use and control of natural resources in the Daw La Lake and the Kaw $\mathrm{Ku}$ Island, and in responding to the threat to their livelihoods posed by the plans for the Hatgyi Dam upstream.

At the local-scale, the Karen communities around Daw La Lake and on Kaw $\mathrm{Ku}$ Island have sought to claim their Rites to access resources based on their customary practices and situational knowledge. Procedurally, they have sought to develop a democratized inclusive grassroots approach to resource management, working with the NGO KESAN in the CBWG project. The opportunity to undertake the CBWG activities reflects the changing political arenas in Myanmar since 2010 when the semi-civilian government was elected. It is an example of how communities and civil society are working together to undertake action research as a basis for influencing decision making and promoting both Rites and Rights (see also, Lamb et al., Chap. 7, this volume). The claims for Rites and Rights by the communities around Daw La Lake and on Kaw Ku Island along the Salween River are the basis of claims for political authority for local resource management.

The subnational level is a second scale around which communities Rights and Rites are being contested, and at which justice is sought. Under the current 2008 Constitution, a key challenge for the Karen communities around Daw La Lake and 
on Kaw $\mathrm{Ku}$ Island is to render their claims for community ownership Rights to be legally recognized by the Karen Regional Government. This recognition is important given the potential threats to their claims from other competing plans, ranging from granting the Daw La Lake as a private fishing concession, to the threat to their local resources if the Hatgyi Dam were to be built upstream.

Cutting across the national, subnational and local scales, the ongoing peace negotiation between the Union government and ethnic armed organizations, including the KNU, is a key arena of justice that relates to restructuring the current political system in Myanmar towards a federal system. Within the peace negotiations, the issue of resource sharing is a key issue to be addressed, and must address all three dimensions of justice: distributional; procedural; and recognitional (BEWG 2017). The importance of the outcome of these peace negotiations cannot be understated in terms of the implications for riverside communities along the Salween River.

Finally, decisions largely claimed to be national by the Union Government regarding the proposed Hatgyi Dam have led to a centralized and opaque formal decision-making process that has excluded communities and civil society groups to date. Despite this, riverside communities and civil society groups have challenged the proposed Hatgyi Dam project on the basis that it threatens both their Human Rights and cultural identity (i.e. Rites-based practices). This is not to suggest that there have not been significant improvements in civil and political freedoms in Myanmar overall since the transition from a military to a semi-civilian government, yet in the case of the Hatgyi Dam decision-making remains lacking in accountability.

In conclusion, I propose that water governance in an ethnically diverse area, such as in the Salween River basin, will create more positive outcomes when both a Rights-based and Rites-based perspectives are integrated. Thus, formal state policies and institutions in Myanmar must become better informed by a Rights-based approach while also accommodating the Rites-based perspectives of communities via creating policy platforms that enable inclusive decision-making in water governance and therefore social justice on the Salween River.

\section{References}

Badenoch, N., \& Leepreecha, P. (2011). Rights and rites: Local strategies to manage competition for water resources in Northern Thailand. In K. Lazarus, N. Badenoch, N. Dao \& B. Resurreccion (Eds.), Water rights and social justice in the Mekong Region. London, United Kingdom: Earthscan.

BEWG (Burma Environment Working Group). (2017). Resource federalism: a roadmap for decentralised governance of Burma's natural heritage.

BRN (Burma Rivers Network). (2017, March 14). Countrywide gatherings on International Rivers Day to oppose large dams in Burma's conflict zones. Statement by Burma Rivers Network (BRN), Save the Salween Network (SSN) and the Burma Environment Working Group (BEWG).

Doran, D., Christensen, M., \& Aye, T. (2014). Hydropower in Myanmar: Sector analysis and related legal reforms. International Journal on Hydropower and Dams, 21(3), 87-91. 
Dore, J. (2014). An agenda for deliberative governance arenas in the Mekong. Water Policy, 16, 194-214.

Fawthrop, T. (2016). Mega Dams on Thanlwin. [Documentary film]. Democratic Voice of Burma and Karen Environmental and Social Action (Producer). Retrieved from: https://www.youtube. com/watch?v=AEt6bagvt6w.

Htwe, C.M. (2016, July 8). Hydropower dams, major development projects suspended in Shan State: minister. Myanmar Times. Retrieved from: https://www.mmtimes.com/national-news/ 21276-hydropower-dams-major-development-projects-suspended-in-shan-state-minister.html.

Jolliffe, K. (2016). Ceasefires, governance and development: The Karen National Union in times of change. The Asia Foundation.

KESAN (Karen Environmental and Social Action Network). (2018). Community based water governance: A briefing report on Daw Lar Lake. Yangon, Myanmar: KESAN. Forthcoming.

KHRG. (2009). Over 3,000 villagers flee to Thailand amidst ongoing SPDC/DKBA attacks. Retrieved from: http://khrg.org/2009/06/09-3-nb1/over-3000-villagers-flee-thailand-amidstongoing-spdcdkba-attacks.

KHRG (Karen Human Rights Group) \& KRW (Karen Rivers Watch). (2018, June). Development or destruction? The human rights impact of hydropower development in villages in Southeast Myanmar. Retrieved from: http://khrg.org/2018/07/18-1-cmt1/development-or-destructionhuman-rights-impacts-hydropower-development-villagers.

KPSN. (2015, July 10). Statement of Karen Peace Support Network.

KPSN (Karen Peace Support Network). (2018). Burma's dead-end peace negotiation process: A case study of the land sector.

KRW (Karen Rivers Watch). (2014). Afraid to go home: Recent violent conflict and human rights abuses in Karen State.

KRW (Karen Rivers Watch). (2016). Karen State September 2016 Conflict: The real motivations behind renewed war.

Lazarus, K., Badenoch, N., Dao, N., \& Resurreccion, B. (Eds.). (2011). Water rights and social justice in the Mekong Region. London, United Kingdom: Earthscan.

Magee, D., \& Kelley, S. (2009). Damming the Salween River. In F. Molle, T. Foran \& M. Käkönen (Eds.), Contested waterscapes in the Mekong Region: Hydropower, livelihoods and governance (pp. 115-140). London, United Kingdom: Earthscan and USER (Chiang Mai University, Thailand).

Middleton, C., \& Pritchard, A. (2016). Arenas of water justice on transboundary rivers: A case study of the Xayaburi Dam, Laos. In D. Blake \& L. Robins (Eds.), Water governance dynamics in the Mekong (pp. 57-88). Petaling Jaya, Malaysia: Regional Strategic Information \& Research Development Centre.

Phyu, A.S. (2016, July 11). Re-launched committee to manage water resources. Myanmar Times. Retrieved from: https://www.mmtimes.com/national-news/21276-hydropower-dams-majordevelopment-projects-suspended-in-shan-state-minister.html.

Salween Watch. (2016). Current Status of Dams on the Salween River - February 2016. Retrieved from: https://www.internationalrivers.org/resources/11286.

South, A. (2018). 'Hybrid governance' and the politics of legitimacy in the Myanmar peace process. Journal of Contemporary Asia, 48:50-66.

SSN (Save the Salween Network). (2016). Statement of Save the Salween Network in YangonFebruary 2016.

TERRA (Towards Ecological Recovery and Regional Alliance). (2006). Chronology of Salween dam plans (Thailand and Burma). Retrieved from: http://www.terraper.org/web/sites/default/ files/key-issues-content/1305712134_en.pdf.

TERRA (Towards Ecological Recovery and Regional Alliance). (2014). Chronology of Hatgyi Dam From 1996-October 2014. Retrieved from: http://www.terraper.org/web/sites/default/ files/key-issues-content/1421399932_en.pdf. 
Wade, F. (2012, February 15). Myanmar: Ceasefire does not mean peace. Aljazeera Opinion. Retrieved from: https://www.aljazeera.com/indepth/opinion/2012/02/201221211854783599.html. Walker, G. (2012). Environmental justice: Concepts, evidence and politics. London and New York: Routledge.

Open Access This chapter is licensed under the terms of the Creative Commons Attribution 4.0 International License (http://creativecommons.org/licenses/by/4.0/), which permits use, sharing, adaptation, distribution and reproduction in any medium or format, as long as you give appropriate credit to the original author(s) and the source, provide a link to the Creative Commons license and indicate if changes were made.

The images or other third party material in this chapter are included in the chapter's Creative Commons license, unless indicated otherwise in a credit line to the material. If material is not included in the chapter's Creative Commons license and your intended use is not permitted by statutory regulation or exceeds the permitted use, you will need to obtain permission directly from the copyright holder.

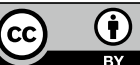

